\title{
The Influence of Profitability and Income Tax on Income Smoothing Rankings
} RATNANINGRUM

Sekolah Tinggi Ilmu Ekonomi Trianandra, Kartasura 57166, Indonesia

Email correspondence: ratna_msi@yahoo.co.id

\begin{abstract}
Income smoothing is logical and rational action that managers attempt to reduce abnormal variation in earnings using special tools in accounting. The objective of this study is to investigate the influence of profitability and income tax on income smoothing rankings of the companies in basic industry and chemical sectors listed in Indonesia Stock Exchange. Statistical sample of the present study is formed from 45 companies in 2014. ROA is used as the proxy of profitability. In calculating the income smoothing, it is used Tucker-Zarowin (TZ) statistic for five year from the year 2010 to 2014 amounted to 225 firm-years observations. Income smoothing is measured by the negative correlation between the change in discretionary accruals and change in pre-discretionary income. The results from the hypotheses testing indicated that there is a negative and significant relationship between profitability and income smoothing. However, it is also found that there is no significant relationship between variables of income tax and income smoothing.
\end{abstract}

Key words: profitability, income tax, income smoothing rankings, Tucker-Zarowin (TZ) statistic.

\section{Pengaruh Profitabilitas dan Pajak Penghasilan terhadap Tingkatan Perataan Penghasilan}

\begin{abstract}
Abstrak
Perataan penghasilan merupakan tindakan logis dan rasional bahwa manajer berusaha untuk mengurangi variasi abnormal pada laba menggunakan alat khusus dalam akuntansi. Tujuan dari penelitian ini adalah untuk mengetahui pengaruh profitabilitas dan pendapatan pajak pada peringkat perataan laba dari perusahaan di sektor industri dan kimia yang terdaftar di Bursa Efek Indonesia. sampel statistik dari penelitian ini terbentuk dari 45 perusahaan di tahun 2014. ROA digunakan sebagai proxy dari profitabilitas. Dalam menghitung perataan laba, digunakan Tucker-Zarowin (TZ) statistik selama lima tahundaritahun 2010-2014sebesar225 perusahaan-tahun pengamatan. perataan labadiukurdengan korelasi negatifantara perubahan akrual diskresioner dan perubahan pendapatan pra-discretionary. Hasil dari pengujian hipotesis menunjukkan bahwa ada hubungan negatif dan signifikan antara profitabilitas dan perataan penghasilan. Namun, juga ditemukan bahwa tidak ada hubungan yang signifikan antara variabel pajak penghasilan dan perataan penghasilan.
\end{abstract}

Kata kunci: profitabilitas, pajak penghasilan, tingkatan perataan penghasilan, Tucker-Zarowin (TZ) statistik. 


\section{INTRODUCTION}

The financial report is a tool for communicating financial information to the parties concerned. For owners of the company, the financial statements as a means to look at the accountability of managers to manage the resources of the company. For investor and creditor, the financial statements are expected to provide information for decision making related to the funds they have invested in the company. Besides beneficial for capital market investors, the financial statements is also a means to account for what was done over the management of resource owners (Belkaoui, 2000).

According to Schroeder (2001), the basic assumptions of agency theory is that every individual trying to do everything to the fullest to optimize interests between principal and agent. Shareholder as a principal makes a contract to maximize their well-being with an ever-increasing profitability. The manager as agent is motivated to maximize the fulfillment of economic and psychological needs, such as: salary, bonuses, loans, or contractual compensation. Agency problem arises because the opportunistic behavior of the agent, i.e. behavior management to maximize their own welfare as opposed to the interests of the principal. For that, management makes earnings management because profit is often used as a basis in determining management compensation and one of the necessary information to do income smoothing.

Besides the responsibility of displaying the best performance of the company, management is also responsible for providing financial reports to all parties concerned with corporate accounting information. In preparing the financial statements, the accrual basis is preferred because it is more rational and fair in reflecting the financial condition than the cash basis. Accrual accounting provides information for corporate earnings and better measurement of corporate performance information. But the weakness of accrual accounting gives management flexibility in choosing the method of accounting as long as for not deviate from applicable accounting standards. Richardson et al. (2002) prove that the information accrual especially operating and investment is a key indicator of earnings manipulation.
Earnings have potential important information for internal and external parties. Income is one indicator to measure performance of company management. Shareholders and other stakeholders are always reacting to all the information related to the earnings because it will affect the value of their investment in the company. Investors' attention is often focused solely on the information provided by the company profits rather than on the procedures that companies use to generate income information, so that it provides an opportunity for managers to take action earnings management by way of income smoothing. This action is done by managers with the aim of creating a stable profit, so it can affect investors' assessment of corporate performance. If the assessment of good company, it is expected that stock prices and stock returns increase (Assih \& Gudono, 2000).

According to Hepwort (1953) with adapting Jatiningrum (2000), states that the income smoothing performed by management is an act that is logical and rational for managers, this was due to several reasons, namely: 1) As engineered to reduce profits and increase costs in the period walking can reduce tax liability. 2) Measures of income smoothing can enhance investor confidence, as it supports the stability of earnings and dividend policy according to the wishes. 3) Measures of income smoothing can strengthen the relationship between managers and employees because it can avoid the demand for higher wages / salaries by employees. 4) Measures of income smoothing have psychological impacts on the economy, where progress and setbacks can be compared and a wave of optimism and pessimism can be suppressed.

Basically, the income smoothing action is expected to provide value to the stock and evaluating the performance of management. An effort to reduce fluctuations in earnings is a form of earnings manipulation so that the amount of profit from a period is not too different from the amount of profit from the previous period. Therefore smoothing earnings include the use of certain techniques to reduce or enlarge the amount of profit from a period equal to the amount of profit from the previous period (Salno \& Baridwan, 2000).

Mohebi, et al. (2013) examine the effect of variable 
specific accounting of the income smoothing, have found that there is influence of firm size and ownership structure of the income smoothing, while profitability has no effect on income smoothing. Hidayat et al. (2016) examine the effect of comprehensive income, company size, profitability and financial leverage on income smoothing on consumer goods companies in the manufacturing sector listed on the Stock Exchange. Income smoothing action is detected using Eckel index. The results show that company size influences the actions of income smoothing, profitability and financial leverage did not affect the income smoothing action, and the consolidated statements of comprehensive income smoothing influence action.

Alexandri et.al. (2014) examine the factors influencing income smoothing action on go public national private commercial bank foreign exchange. The results show that company size, profitability and financial leverage effect on the income smoothing. These findings are consistent with studies by Jatiningrum (2000); Ashari et al. (1994) which show that the practice of income smoothing was affected by the profitability.

Asuman (2009) detect the behavior of income smoothing in the go public company in Turkey, using the discretionary accounting changes (DACs). Samples are classified into groups of non-smoother and smoother to use the index Moses income smoothing behavior. The result shows that motivation that allows of DACs are: income smoothing, economic characteristics in the period did DACs, and the desire of the company to report earnings close to zero.

Namazi and Khansalar (2011) examine the income smoothing action of the two types of companies, an established and emerging company in the stock market Tehran, using a model of Jones. The results prove that the discretionary accruals of growing company tend to apply more intensive than already established companies. Eckel models is also used to detect income smoothing with results show that income smoothing on a growing company is larger than the incumbents. Kangarlouei et al (2012) investigate the effect of income smoothing on the quality of reported earnings of the active collapsed companies in TSE. The results express a very weak correlation relationship between variables, but prove the concept that the main purpose of the collapsed companies' managers from manipulation of profit and loss figures was merely to maintain their firms in the capital market and to prevent dropping of the market value of the firm. The research by Luqman and Shahzad (2012); Saedi (2012) show that the tax has no significant relationship with income smoothing. While Tanomi (2012) show that the tax has no effect on earnings management. Bahardian et al. (2013) find no significant difference between companies doing income smoothing with no income smoothing in the previous period on a tax adjustment assertiveness and decrease in tax diagnostic difference.

Knowledge of the effect of taxes on income smoothing is expected to be input to the government about a possible link between taxes with income smoothing rankings. For investors and other stakeholders, the expected profitability of knowledge on the relationship with income smoothing rankings can provide a base for decisions relating to the investment in the company and the anticipation that needs to be done.

\section{LITERATURE REVIEW}

\section{Income Smoothing}

Income smoothing closely related to the concept of earnings management. Agency theory states that the practice of earnings management is influenced by conflicts of interest between the management (agent) and the owner / investor (principal). Agent is motivated to maximize the economic needs and psychology, among others, in terms of acquiring an investment, loan, or contractual compensation, triggering a conflict of interest between principal and agent. The principal also have their own motivations, which is for the welfare of themselves through the company's profitability is always increasing. Principal assumed to be only interested in financial returns obtained from their investment in the company. Meanwhile the agency is assumed to receive the satisfaction not only of financial compensation, but also of other extras involved in the agency relationship (Anthony and Govindarajan, 2005). In accordance with this assumption, then the manager will adopt policies that benefit themselves before providing benefits to shareholders. According to Schroeder (2001), the basic assumptions of agency theory is 
that each is the condition that causes the particular policies conducted by the management company without the knowledge of the investor. Policies that are intended are actions in the form of earnings management, which is one of the patterns is in the form of income smoothing.

Hepworth (1953 in Tucker \& Zarowin 2006) obtain empirical evidence that investors and creditors of a company will feel more confidence in corporate management that can report stable profit, so it is something that is logical and rational for managers to try to flatten profit using accounting devices. The same thing also expressed Beidleman (1973 in Tucker \& Zarowin, 2006), that income smoothing is an enterprise management effort to reduce abnormal variations in earnings to the extent permitted by the principles of accounting and management.

Koch (1981) defines that income smoothing is a method used by management to reduce fluctuations in reported earnings to match the desired target either artificial (artificial smoothing), and in real terms (real smoothing). This action has been considered a common action performed by the management company. According to Eckel (1981) there are two types of income smoothing is naturally smooth and intentionally smooth. Natural flow of income smoothing (income smoothing naturally) simply has implications that the nature of the process itself profits that generate a stream of income or profits flat. In contrast to the naturally income smoothing, income smoothing intentional (intentionally income smoothing) containing management intervention, in the form of this there are two (2) types of income smoothing action, as follows: first artificial smoothing ie income smoothing action that occurs when the current set of management accounting to produce a stream of average earnings. Second real smoothing, which measures income smoothing that occurs when management takes action to use transactions or economic events in the company resulting in a flow of profits evenly.

\section{The Influence of Income Tax on Income Smoothing Rankings}

Tax is one of the costs that are very important in the company. The company will always try to reduce tax expenditures and maintain the company's liquidity.
According to the agency theory, management will always act in their interest that is not sure enough yet aligned with the interests of shareholders and the government, so they will take tax policy to reduce costs. For example, they manipulate the revenue and costs in order to transfer the tax expense to the later period (Bahadori et. al., 2013).

Earnings that are too high will increase the tax to be paid by the company, whereas the profit drop too low will show the company's performance poor, so there is a possibility that management make reported earnings do not fluctuate by way of smoothing earnings to avoid paying taxes too high. This is because the payment of this tax will add cash expenditure; the burden of this tax will reduce the company's liquidity (Saedi, 2012).

This increased profit has made the company must pay more taxes than before. However, if the declining profitability is too low, it will cause the manager's performance is considered poor. Then manipulate earnings will probably be an option for the manager so that the tax paid is not too high at a time so performance management is still considered good by the shareholders. This will make the management is trying to shift income from one year to the next in order to obtain the most minimal tax payments. The earnings manipulation is included in income smoothing. Tax is allegedly have an influence on income smoothing because it has a direct link with earnings, where a conflict of interest between the management who wants the tax payments to be as small as possible, while the government wants to levy taxes as high as possible. With income smoothing, management hopes that lower taxes paid.

The findings of research undertaken by Luqman \& Shahzad (2012); Saedi (2012) show that the tax has no significant relationship with income smoothing. Meanwhile, Pratiwi \& Handayani (2014) state that the tax does not affect the income smoothing practices, as well as Tanomi (2012) proves that the tax has no effect on earnings management. Bahadori et. al., (2013) find no significant difference between smoother and non-smoother in the previous period on a tax adjustment assertiveness and decrease in tax diagnostic difference. Based on the description above, the hypothesis proposed in this study are: 
H1: Income Tax has positive influence on Income Smoothing Rankings

The Influence of Profitability on Income Smoothing Rankings

Profitability is the ability of the company to make a profit. One measure of profitability ratios is return on assets (ROA). ROA is the ratio used to measure the ability of management to gain an advantage over the source of funds owned companies. The companies with a low return on assets have a greater tendency to smooth earnings. It was alleged that fluctuations in earnings which will have an impact on the lower or declining profitability will encourage managers to smooth earnings (Ashari et al., 1994). Fluctuations can be presumed that declining profitability will have a tendency for a company to do the practice of smoothing earnings to make it appear that the company looked healthy in the eyes of external companies. Fluctuations in lower profitability or decreases have a tendency for the company to do the income smoothing, especially if the company establishes bonus compensation scheme is based on the amount of profit generated. The previous study on the profitability suspected as one of the factors that influence the practice of income smoothing, did not give the same results.

According Ashari et al. (1994); profitability is said to be one of the factors that influence income smoothing. While the research results Widaryanti (2009), Sherlitaa \& Kurniawan (2013), Mohebi (2013), Hidayat, et. al. (2016) conclude that profitability does not affect the income smoothing. Fengju et.al. (2013) find that there are significant differences in financial leverage and profitability between smoother and non-smoother company. Based on the description above, the hypothesis proposed in this study are:

H2: Profitability has negative influence against income smoothing rankings

\section{METHOD}

\section{Research Sample}

The population observed in this study is a group of manufacturing companies in the type of base and chemical industry listed on the Jakarta Stock Exchange (JSX). Samples were selected based on the method of purposive sampling with the following criteria: 1)
The company is registered as from 1 January 2010 up to December 31, 2014 (there are 64 companies) 2) Data Incomplete (13 companies), 3) Currency used inconsistently in the report finances during the period (6 companies). 4) The final number of companies included in this study is 45 companies or 225 observations.

\section{Operational definition and measurement of variables} Income smoothing is a method used by management to reduce fluctuations in reported earnings to match the desired target either artificial term (artificial smoothing), and in real terms (real smoothing). In our model, the author uses the income smoothing rankings as a proxy for income smoothing practices by the company. To determine the rankings of income smoothing, we use discretionary accrual models with modified Jones in Kothari et al. (2005), which is defined by Tucker and Zarowin (2006). Return on assets (ROA) was added as an additional control variable because previous research finds that the Jones model is misspecification for well performing or poorly performing firms (Dechow (1995); Kothari et. al (2005) in Tucker \& Zarowin, 2006).

To estimate discretionary accruals, we use the cross sectional version of the Jones model, modified by Kothari,et al (2005). The following is the discretionary accruals calculation model.

Accruals $_{\mathrm{t}}=\mathrm{a} \frac{1}{\text { Assetst }-1}+\mathrm{b} \Delta$ Sales $_{\mathrm{t}}+\mathrm{cPPE} \mathrm{P}_{\mathrm{t}}+\mathrm{d}$

$\operatorname{ROA} t+\mu$

In Regression (1), total accruals (Accruals); changes in sales ( $\triangle$ Sales); and gross property, land and equipment (PPE) are each deflated by the initial asset. Nondiscretionary accruals (NDAP) are the fitted value of regression (1) and discretionary accruals (DAP) are the deviations of actual accruals from NDAP. Prediscretionary income (PDI) is calculated: net income minus discretionary accruals (PDI = NI - DAP).

The Measurement of income-smoothing (IS) obtained from the correlation between changes in discretionary accruals and change in pre-discretionary income: Corr ( $\triangle \mathrm{DAP}, \triangle \mathrm{PDI})$, using the current years and past four years observations. This measure assumes that there is underlying pre-managed 
income series and the managers use discretionary accruals to make the reported series smooth (Tucker and Zarowin, 2006). This study use a technique of inverted rankings (reversed fractional rankings). As result, firms with more negative correlation receive a higher income smoothing rankings (between 0 dan1). If the pre-managed high income is high, will be negative discretionary accruals to reduce earnings. Whereas, if the pre-managed income is low, will be positive discretionary accruals to increase earnings. The use of Tucker and Zarowin models (2006) is that distinguishing this study with previous research, where most of the research on income smoothing index models wearing Eckel (1981) in detecting income smoothing. The author uses this model with the consideration that this model is able to explain the influence of the factors studied was compared using Eckel Index (Aji and Mita, 2010).

Income tax is a tax levied on the company's net operating income or operating income minus net financial costs. The measurement of income tax is obtained by the subtracting income before tax from income after tax in 2014. Profitability is the company's ability to generate profits in a given period. Profitability is measured by the ability of companies to use assets productively by comparing the profits derived by the number of assets. The Measurements using ROA as this ratio provides a better measure for the profitability of the company because it shows the effectiveness of management in using assets to make a profit, with the following formula:

Return Of Assets $=\frac{\text { Net profit after tax }}{\text { Assets }} \times 100 \% \ldots$

\section{Analysis method}

The analytical method used in this research is the multivariate regression. Statistical models to test the research hypotheses are:

IS $=a+\beta_{1} \ln \mathrm{PAJAK}+\beta_{2} \ln \mathrm{ROA}+\varepsilon$

Notation :
IS $\quad:$ Income Smoothing Rankings
PAJAK : Income Tax
PROF : Profitability

\section{RESULTS AND DISCUSSION}

This study examines the effect of profitability and the income tax on income smoothing rankings. In this study, the period to test the research model was using the observation period of the year 2014 . The total company used in this study is as much as 45 companies. As for detecting income smoothing rankings, we use the observation period between 2010-2014. Thus, in detecting the income smoothing rankings, there is a number of 225 firms observations. The following are the results of descriptive statistics which show the characteristics of the data that is used as a sample.

This study used Discretionary Accrual (DAP) as a proxy of earnings management variables. DAP-forming component consists of total accruals (TA), total assets $(A)$, fixed assets (PPE), sales change ( $\triangle$ SALES), and Return on Assets (ROA). Descriptive statistics of DAP and its components are presented in Table 1.

Table 1 Descriptive Statistics of Discretionary Accruals

\begin{tabular}{|c|c|c|c|c|}
\hline & Minimum & Maximum & Mean & $\begin{array}{c}\text { Standard } \\
\text { Deviasi }\end{array}$ \\
\hline $\begin{array}{l}\text { Total } \\
\text { Accruals/ } \\
\text { Assets }_{\mathrm{t}-1}\end{array}$ & $-12,42$ & 2,16 & $-0,0767$ & 0.85620 \\
\hline $\begin{array}{c}\text { Total Assets/ } \\
\text { Assets }_{\mathrm{t}-1}\end{array}$ & 0.00 & 0.00000345 & 0.0000001898 & - \\
\hline $\begin{array}{l}\triangle \text { SALES/ } \\
\text { Assets }_{\mathrm{t}-1}\end{array}$ & $-9,47$ & 149,64 & 0,9149 & 10,41278 \\
\hline $\begin{array}{c}\text { PPE/ Assets } \\
\mathrm{t}-1\end{array}$ & 0,00 & 250530,75 & 1985,3985 & 19830,20608 \\
\hline ROA & $-1,25$ & 0,58 & 0,0525 & 0,14765 \\
\hline DAP & $-6,18$ & 2,73 & $-0,159$ & 0,97854 \\
\hline
\end{tabular}

Total Accruals / Assets $t-1$ presents minimum value of -12.42 , maximum of 2.16 with an average of -0.0767 . With the average value is negative, it can be concluded that in general, the cash value of the company's operations is in excess of the net income (the total accrual is the net amount of net income and cash flow operation). Total Assets / Assets $\mathrm{t}-1$ has a minimum value of 0.00 , maximum value of 0.00000345 , and average value of 0.0000001898 . By an average positive value indicates that the average company of the sample has a larger asset base than the previous year asset. 
PPE / Assets $t-1$ is the value of fixed assets with a minimum value of 0.00 , maximum value of $250,530.75$ and average value of 1985.3985 . The positive value of the average fixed assets shows that the average fixed assets current year is greater than the total assets of the previous year. ROA shows the minimum value of -1.25 , maximum value of 0.58 and average value of 0.0525 indicates that in general the company became the sample is profitable enough. The value of DAP is from -6.18 up to 2.73 with an average of -0.159 . DAP as a proxy of earnings management shows a negative average value indicates that the sample companies generally perform earnings management by lower earnings (income decreasing discretionary accruals). To calculate income smoothing is used the correlation between DAP changes with changes in PDI. Table 2 presents the variable of Income Smoothing with the components that make it up.

Table 2 Descriptive Statistics of Income Smoothing

\begin{tabular}{ccccc}
\hline & Minimum & Maximum & Mean & $\begin{array}{c}\text { Standard } \\
\text { Deviasi }\end{array}$ \\
\hline PDI & $-9,86 \times 10^{-11}$ & $3,22 \times 10^{12}$ & $2,774 \times 10^{10}$ & $2,327 \times 10^{11}$ \\
& & & & \\
$\Delta$ DAP & $-5,91$ & 5,83 & 0,0318 & 1,27788 \\
$\Delta$ PDI & $-3,22 \times 10^{-12}$ & $9,67 \times 10^{11}$ & $-1,31 \times 10^{10}$ & $2,567 \times 10^{11}$ \\
$\begin{array}{c}\text { Corr. }(\Delta \\
\text { DAP, } \Delta \text { PDI) }\end{array}$ & $-0,99$ & 0,99 & 0,1917 & 0,68929 \\
\hline Source: Data processed & & &
\end{tabular}

PDI represents the excess of net income to discretionary accruals that shows the value of $-9.86 x$ $10^{-11}$ up to $3.22 \times 10^{12}$ with an average value of 2.774 $x 10^{10}$. With an average positive PDI can be concluded that the overall value discretionary accruals is greater than the net profit. $\triangle$ DAP value varies from -5.91 up to 0.0318 with an average of 0.0318 . That shows that the average DAP current year is larger than the previous year. Meanwhile the $\triangle P D I$ value varies from $-3.22 \times 10^{-12}$ up to $-3.22 \times 10^{-12}$ with an average of $-1.31 \times 10^{10}$. It can be concluded that the average PDI current year is less than the previous year.

The main variables in this study are income smoothing rankings, Ln Profitability, and Ln Taxes, with the results of descriptive statistics as presented in the following table.
Table 4 The Results Of Regression Analysis from The Influence of Profitability and Income Tax against Income Smoothing Rankings

\begin{tabular}{ccccc}
\hline Variables & $\begin{array}{c}\text { Regression } \\
\text { coefficient }\end{array}$ & $\begin{array}{c}\text { Error } \\
\text { Standard }\end{array}$ & t value & p value \\
\hline Constant & 0.397 & 0.094 & 4.2378 & 0.000 \\
Ln PROF & -0.056 & 0.024 & -2.302 & 0.026 \\
Ln PAJAK & -0.004 & 0.005 & $-0,852$ & 0.399 \\
R Square & 0.157 & & & \\
Adjusted R & & & 0.080 & \\
F value & & & 2.913 & \\
$\begin{array}{l}\text { Probability } \\
\text { of F value }\end{array}$ & & 0.065 & \\
Source: Data processed & & &
\end{tabular}

\section{Coefficient of determination and $F$ value}

The result of the coefficient of determination for the regression equation shows the value of adjusted $R$ square of 0.080 . This shows that the $8.0 \%$ change in the variable income smoothing variations can be explained by the company's profitability and income tax. The $F$ value test results demonstrate the $F$ value of 2.913 with $p$ value of 0.065 so it can be inferred that the regression model has fit with the data used with $\alpha$ of $10 \%$.

\section{t value}

Hypothesis 1 was aimed to test the effect of profitability on the rankings of income smoothing. From Table 4 it is known that variable Profitability has a regression coefficient of -0.056 with a $p$ value of 0.026 . Testing yields a significant result so that it can be concluded that there is negative effect of the profitability on income smoothing rankings. This indicates that the higher profitability of the company, the lower the company's rating in income smoothing, and vice versa. The higher the level of corporate profitability, the company will tend to not perform income smoothing because the company increasingly into the public spotlight, so the company is likely trying to prevent acts that jeopardize the credibility of the company. These results support the findings of Ashari, et al. (1994), Saedi (2012), and the opposite direction by Budiasih (2009) which is show a positive association between profitability and income smoothing,

Hypothesis 2 aims to examine the effect of taxes on income smoothing rankings. Regression test results show the value of regression coefficient of -0.004 with 
$p$ value of 0.399 . it can be concluded that the tax does not affect the income smoothing so the hypothesis 2 is not supported. This finding is consistent with research Pratiwi \& Handayani (2014) which shows that the tax does not affect practice income smoothing. This indicates that the level of the tax does not affect high and low of income smoothing rankings.

The results of this study do not support the results of Saedi (2012) and Luqman \& Shahzad (2012) which states that there is a significant correlation between the income tax with income smoothing practices. Researchers speculate that this hypothesis is not proven, it is likely to minimize taxes, managers prefer ways other than income smoothing practices.

\section{CONCLUSIONS}

Income smoothing is an effort to normalize the income in order to achieve the desired level. Allegedly fluctuations in earnings impact decreasing profitability that encourages managers do income smoothing, income smoothing in addition to the manager aims to minimize the taxes to be paid. The results of this study indicate that the negative effect on the profitability rankings income smoothing. This proves that the lower profitability of the income smoothing the higher rank or higher in the practice of smoothing earnings, and vice versa. Another finding is that the income tax has no effect on the rankings of income smoothing.

Limitation of this study is lied one the sample employed which is included only the companies from the basic and chemical industries. For further research should be expanded so that the type of company sufficient number of samples so the results are representative. From the results of this study show that the income tax has no effect on the rankings of income smoothing, researchers surmise that in order to minimize the taxes, the manager choose another way than do income smoothing, for it should in future research the model Tucker and Zarowin (2006) compared with the other measurement model of income smoothing.

\section{REFERENCES}

Alexandri, M. B., \& Anjani, W. K. (2014). Income smoothing: impact factors, evidence in
Indonesia. International Journal of Small Business and Entrepreneurship Research, 3(1), 21-27. Retrieved from http://www. eajournals.org

Anthony, R. \& V. Govindarajan. (2005). Sistem Pengendalian Manajemen, translator: Kurniawan, $T$. Jakarta: Salemba Empat.

Ashari, N., Koh, H. C., Tan, S. L. \& Wong, W. H. (1994). Factors affecting income smoothing among listed companies in Singapore. Accounting and Business Research, 24 , 291-301. DOI:1 0.1080/00014788.1994.9729488Nasuhiyah

Aji, D. Y. \& Mita, A. F. (2010). Pengaruh profitabilitas, risiko keuangan,nilai perusahaan, dan struktur kepemilikan terhadap praktek perataan laba: studi empiris perusahaan manufaktur yang terdaftar di BEI. SNA XIII. Purwokerto.

Assih, P. \& Gudono, M. (2000). Hubungan tindakan perataan laba dengan reaksi pasar atas pengumuman informasi laba perusahaan yang terdaftar di Bursa Efek Jakarta. Jurnal Riset Akuntansi Indonesia, 3 , 35-53.

Asuman, A. (2009). Detecting income-smoothing behaviors of turkish listed companies through empirical tests using discretionary accounting changes. Critical Perspectives on Accounting, 20 , 591-613. DOI 10.1016/j. cpa.2008.01.003

Bahardian, M., Abdoli, M. \&. Nia, G. T (2013). A study of the impact of the income smoothing and prior period adjustments on tax assertiveness and tax diagnostic difference decrease in Tehran Stock Exchange. Journal of Life Science and Biomedicine, 3, 339-343. Retreived from http://jlsb.science-line.com/

Belkaouli. (2000). Teori Akuntansi. Buku 1. Translator: Marwata, et.al. Jakarta: Salemba Empat.

Budiasih, I. (2009). Faktor-faktor yang mempengaruhi praktik perataan laba. Jurnal Akuntansi dan Bisnis, 4, 44-50. Retreived from ojs.unud. 
JURNAL BISNIS \& MANAJEMEN

ISSN 1412 - 3681

ac.id/index.php/jiab/article/view/2589

Eckel, N. (1981). The Income Smoothing Hypothesis Revisited. Abacus. 17 (1), 28-40.

Fengju, X. R., Fard, Y., Maher, L. G. \& Akhteghan. N. (2013). The relationship between financial leverage and profitability with an emphasis on income smoothing in Iran's Capital Market. European Online Journal Of Natural And Social Sciences, 2, 156-164. http:// www.european-science.com

Hidayat, B. A., E., Kanam \& Widyaningsih, R. (2016). The effect of reported comprehensive income firm size, profitability and leverage on income smoothing (study on companies of consumer goods on manufacturing sector listed in Indonesia Stock Exchange), Retreived from http://ssrn.com/ abstract=2731472, accessed on March 22, 2016

Jatiningrum. (2000). Analisa faktor-faktor yang berpengaruh terhadap perataanpenghasilan bersih/laba pada perusahaan yang terdaftar di BEJ. Jurnal Bisnis dan Akuntansi, 2 , 145155.

Kangarlouei, S. J., Motavassel, M. \& Rezvani, A. (2012). The investigation of the effect of income smoothing on the reported earnings quality of active collapsed companies in Tehran Stock Exchange (TSE). Global Business and Management Research: An International Journal, 4, 220.-232. Retreived from http://ristekdikti.summon.serialssolutions. com/\#!/search?ho=t\&l=en \&q=income $\% 20$ smoothing

Koch, B. S. (1981). :Income Smoothing : An Experimen "t, The Accounting Review, 56, 574-586.

Kothari, S. P., Leone, A. \& Wasley, C. (2005). Performance matched discretionary accruals. Journal of Accounting and Economics, 39, 161-197. Retreived from http://archive.nyu.edu/bitstream/2451/27 593/3/SSRN-id744708.pdf.txt
Luqman, R. A. \& Shahzad, F. (2012). An association between income smoothing, income tax and profitability ratios in Karachi Stock Exchange (An empirical Investigation). Interdisciplinary journal of Contemporary Research in Busines, 3 , 986-990. Retreived from http://ijcrb.webs.com

Mohebi F., Mahmoodi, M. \& Yadollahzadeh, N. A. (2013). The investigation of the effect of firm-specific accounting variables on income smoothing of companies: evidence from Tehran Stock Exchange. World of Sciences Journal, 1, 109-116, Retreived from http:// WWW.ENGINEERPRESS.COM

Namazi, M. \& Khansalar, E. (2011). An investigation of the income smoothing behavior of growth and value firms (case study: Tehran Stock Exchange market). International Business Research, 4, 84-94. doi:10.5539/ ibr.v4n4p84

Pratiwi, H. \& Handayani, B. D. (2014). Pengaruh profitabilitas, kepemilikan manajerial dan pajak terhadap praktik perataan laba. Accounting Analysis Journal, 3, 264-272. Retreived from http://journal.unnes.ac.id/ sju/index.php/aaj

Richardson, S. A., Tuna, I. \& Wu, M. (2002). Predicting earnings management: the case of earnings restatements). Retreived from: http://ssrn. com/abstract=338681, accessed on May 7, 2016

Saeidi, P. (2012). The relationship between income smoothing and income tax and profitability ratios in iran stock market. Asian Journal of Finance \& Accounting, 4,46-51. doi:10.5296/ ajfa.v4i1.790

Salehi, M. \& Manesh, N. B. (2011). the effect of income smoothing on the informativeness of stock price. Asian Journal on Quality, 12, 80-90. doi:10.1108/15982681111140561

Sherlitaa, E. \& Kurniawan, P. (2013). Analysis of factors affecting income smoothing among 
listed companies in Indonesia. Jurnal Teknologi utm, 64, 17-23. Retreived from http://www.jurnalteknologi.utm.my

Schroeder, R. G., Clark, \& Cathey. (2001). Accounting Theory and Analysis (seventh edition). New York: John Wiley and Sons, Inc.

Tanomi, R. (2012). Pengaruh kompensasi manajemen, perjanjian hutang dan pajak terhadap manajemen laba pada perusahaan manufaktur di Indonesia. Berkala IImiah Mahasiswa Akuntansi, 1, 30-35. Retreived from http://journal.wima.ac.id/index.php/ BIMA/article/view/112
Tucker, J. W. \& Zarowin, P. A. (2006). Does income smoothing improve earning informativeness?. The Accounting Review, 81,251-270. Retreived from https:// warrington.ufl.edu/accounting/docs/TAR_ income_smoothing.pdf

Widaryanti. (2009). Analisis perataan laba dan faktor-faktor yang mempengaruhi pada perusahaan manufaktur di Bursa Efek Indonesia". Fokus Ekonomi, 4, 60-77. Retreived from http://stiepena.ac.id/wpcontent/uploads/2012/11/pena-fokus-vol4-no-2-60-77.pdf 


\section{APPENDICES}

\section{Normality Test}

Table 1 The Result of Normality Test With One Sample Kolmogorov Smirnov Test

\begin{tabular}{llc}
\hline & & $\begin{array}{c}\text { Unstandardized } \\
\text { Residual }\end{array}$ \\
\hline $\mathrm{N}$ & Mean & 45 \\
Normal Parameters (a,b) & Std. Deviation & .0000000 \\
& Absolute & .27351221 \\
Most Extreme Differences & Positive & .115 \\
& Negative & .082 \\
Kolmogorov-Smirnov Z & &.-115 \\
Asymp.Sig. (2-tailed) & & .115 \\
\hline
\end{tabular}

\section{Multikollinearity Test}

Table 2 The Result of Multikollinearity Test

\begin{tabular}{|c|c|c|}
\hline \multirow{2}{*}{ Model } & \multicolumn{2}{|c|}{ Collinearity Statistic } \\
\hline & Tolerance & VIF \\
\hline LN_PAJAK & .997 & 1.003 \\
\hline LN_PROF & .997 & 1.003 \\
\hline
\end{tabular}

\section{Autocorrelation Test}

Table 3 The Result of Autocorrelation Test with Durbin Watson Test

\begin{tabular}{cccc}
\hline DW Value & $\mathrm{dl}$ & $\mathrm{du}$ & $\mathrm{du}<\mathrm{DW}<4$-du \\
\hline 2.032 & 1.430 & 1.615 & $1.615<2.032<4-1.615$ \\
& & & $1.615<2.032<2.385$ \\
\hline
\end{tabular}

\section{Heterokedasticity Test}

Table 4. The Result Of Heterokedasticity Test with Glejser Test

\begin{tabular}{cccccc}
\hline & \multicolumn{2}{c}{$\begin{array}{c}\text { Unstandardized } \\
\text { Coefficients }\end{array}$} & $\begin{array}{c}\text { Standardized } \\
\text { Coefficients }\end{array}$ & $\mathrm{t}$ & Sig. \\
\cline { 2 - 4 } Model & $\mathrm{B}$ & Std. Error & $\mathrm{B}$ & & \\
\hline (Constant) & .260 & 0.047 & & 5.471 & .000 \\
LN_PAJAK & -.001 & .002 & -.091 & -.590 & .558 \\
LN_PROF & .004 & .012 & -.051 & .329 & .744 \\
\hline
\end{tabular}

